DARIA DOMINIAK

0000-0001-6531-8966

Katedra Inteligencji Obliczeniowej

Politechnika Wrocławska

\title{
Eksperyment Banku Światowego oraz Krajowej Administracji Skarbowej w świetle zasad prostego języka
}

\begin{abstract}
Abstrakt
W artykule przedstawiono założenia dotyczące zastosowania prostego języka (plain language) oraz ekonomii behawioralnej w komunikacji urzędowej. Zaprezentowano badanie, które miało na celu sprawdzenie, czy skuteczność ekonomii behawioralnej wykorzystanej w pismach urzędowych stworzonych na potrzeby eksperymentu Banku Światowego oraz Krajowej Administracji Skarbowej przeprowadzonego w Polsce w 2016 roku (Hernandez et al. 2017) łączy się z zasadami prostego języka. Praca ta zawiera porównanie wyników eksperymentu Banku Światowego z wynikami analizy językoznawczej (ilościowej i jakościowej) przeprowadzonej w niniejszym artykule. Autorka sprawdza, czy pisma, które Bank Światowy uznał za najbardziej skuteczne w ściągalności podatków, będą również najlepiej napisane pod względem zasad prostego języka. Postawiona w niniejszej pracy hipoteza zakłada, że pisma stworzone na potrzeby eksperymentu mają różny poziom trudności, co oznacza, że wbrew temu, co przyjęli eksperymentatorzy — różnią się nie tylko techniką nakłaniającą (tak zwanym insightem behawioralnym), ale też stylem. Potwierdzenie tej hipotezy mogłoby rzecz jasna osłabić moc osiągniętych w eksperymencie wniosków.
\end{abstract}

Słowa kluczowe: Krajowa Administracja Skarbowa, ekonomia behawioralna, komunikacja urzędowa, manipulacja, obywatel, perswazja, pismo, plain language, podatek, prosta polszczyzna, prosty język, przystępność tekstu, upomnienie.

\section{Wstęp}

Komunikacja między urzędem a obywatelem poddawana jest dziś wpływom wielu czynników o charakterze ekonomicznym, psychologicznym, społecznym, technologicznym, a nawet lingwistycznym. Okazuje się bowiem, że urzędy dostrzegają zależność między sposobem komunikacji a korzyściami z niej wynikającymi, dlatego też zaczynają korzystać z różnych technik językowych, aby te korzyści zwiększyć. 
Jednym z przypadków takiej interwencji jest polski eksperyment behawioralny, który przeprowadziły Bank Światowy i Krajowa Administracja Skarbowa (KAS). To właśnie ów eksperyment jest przedmiotem tego artykułu.

Ekonomia behawioralna jest dziedziną, która z perspektywy psychologicznej i socjologicznej weryfikuje założenia ekonomii neoklasycznej (Solek 2010: 24-25). W latach osiemdziesiątych XX wieku ekonomiści zauważyli, że nieracjonalność może stanowić regułę analizy procesów finansowych. Za pomocą ekonomii behawioralnej można rozważać zjawisko błędów popełnianych w trakcie podejmowania decyzji. Ekonomia behawioralna bada zachowania człowieka (czyli nawiązuje do behawioryzmu), gdy ten ma podjąć decyzję, jednak jest to spojrzenie bazujące na przykład na szybkości reakcji, motywie socjologicznym czy tonie przekazu (Solek 2010: 24-29).

W 2008 roku Richard H. Thaler oraz Cass R. Sunstein napisali cieszącą się dużą popularnością książkę pod tytułem Nudge. Improving Decisions about Health, Wealth and Happiness (w Polsce ukazała się ona jako Impuls. Jak podejmować właściwe decyzje dotyczace zdrowia, dobrobytu i szczęścia). W 2017 roku Thaler otrzymał Nagrodę Banku Szwecji im. Alfreda Nobla właśnie za wkład w ekonomię behawioralną.

Wraz ze wzrostem popularności ekonomii behawioralnej naukowcy zaczęli zastanawiać się nad jej zastosowaniem w różnych dziedzinach i tak strategię tę wykorzystano w praktycznych przedsięwzięciach (ubezpieczenia społeczne, promocja zdrowego trybu życia, transplantologia, transport) (Olejniczak, Śliwowski 2014: 24-33). Dodatkowo warto wspomnieć o zastosowaniu ekonomii behawioralnej w zwiększeniu ściągalności podatków w Wielkiej Brytanii. Pomysłodawcą tego eksperymentu był Michael Hallsworth, który przeprowadził łącznie dwa badania (natural field experiment [NFE]), które obejmowały aż 200 tysięcy respondentów. Upraszczając, badanie polegało na wysyłaniu listów z przekazem behawioralnym do podatników mieszkających na terenach Anglii, Walii oraz Irlandii Północnej, którzy nie płacili podatków, a musieli rozliczyć się z urzędem skarbowym (Self Assessment) (Hallsworth et al. 2014: 11, za Hernandez et al. 2017).

W niniejszym artykule spróbuję odpowiedzieć na kilka pytań:

1. W jaki sposób eksperci tworzący pisma na potrzeby eksperymentu Banku Światowego oraz Krajowej Administracji Skarbowej przeprowadzonego w Polsce w 2016 roku (Hernandez et al. 2017) wykorzystali strategie ekonomii behawioralnej?

2. Jakie są różnice między pismami w świetle analizy pragmalingwistycznej?

3. Czy pisma behawioralne są zgodne ze standardem prostej polszczyzny?

4. Czy najskuteczniejsze pismo pod względem behawioralnym jest również pismem najprostszym (najbardziej przystępnym)?

5. Jak wyglądałoby upomnienie podatkowe, gdybyśmy połączyli techniki behawioralne i zasady prostego języka?

Za materiał badawczy posłużyło mi dziesięć pism, które użyte zostały w eksperymencie Banku Światowego oraz Krajowej Administracji Skarbowej. Były to pisma z akapitami behawioralnymi (osiem tekstów), bazowe pismo behawioralne oraz 
standardowe pismo wysyłane zwykłą pocztą (zob. aneks). Dodatkowo zredagowałam i zbadałam też nowe pismo - prototyp łączący techniki ekonomii behawioralnej oraz zasad prostego języka. Pisma te poddano wstępnej analizie pragmalingwistycznej (jakościowej) oraz docelowej analizie stylometrycznej (ilościowej). W tym drugim przypadku pisma badano w trzech kategoriach:

- ogólna mglistość języka pism,

- cechy leksykalne pism,

- cechy gramatyczne pism.

Niektóre z tych parametrów określono samodzielnie, wartości innych — pobierano z programów komputerowych lub internetowych aplikacji (Jasnopis 2019; Logios 2019; Lem 2019).

Oceniając wszystkie pisma, zastosowałam metodę sortowania, to znaczy na podstawie wyników w poszczególnych kategoriach stworzyłam kilka rankingów pism (od tekstu najlepszego w danej kategorii do najgorszego). Za miejsca w owych rankingach każde pismo otrzymywało punkty. To one złożyły się na pozycję pisma w końcowym rankingu. Ostatecznym celem tak pomyślanej analizy było zatem porównanie pozycji wszystkich pism po eksperymencie behawioralnym (ranking skuteczności finansowej) z pozycją danego pisma w rankingu stylometrycznym (ranking prostoty języka).

\section{Założenia wrocławskiego modelu prostej polszczyzny}

Istnieje wiele modeli prostego języka, na przykład model anglosaski, skandynawski czy niemiecki. Warto jednak przybliżyć wrocławski model prostego języka, na którym opiera się analiza lingwistyczna pism eksperymentalnych wspomnianych w tym artykule.

Prosty język to metoda tworzenia efektywnych tekstów, to znaczy tekstów czytanych szybko i z mocą, klarownych, oszczędnych, przyjaznych i eleganckich (Piekot 2018b). Prosty język nie oznacza jednak, że komunikaty sporządzone według jego zasad są skierowane tylko do osób z niskim wykształceniem lub do osób niekompetentnych czy mało inteligentnych. W spektrum efektywnej komunikacji, oprócz stylu plain language, można wyróżnić jeszcze dwa style pisania, które są wykorzystywane do procesu poprawy jakości i przystępności tekstów: power writing (efektywne pisanie) oraz easy to read (język łatwy) (Piekot 2018b). Każdy z tych trzech stylów różni się od siebie grupą odbiorców. Używając plain language, tworzy się tekst skierowany do przeciętnego obywatela, a nawet do osób słabo znających język danego państwa. Power writing natomiast stosowany jest w korespondencji i pismach skierowanych do osób, które znajdują się na wysokim stanowisku, jak na przykład dyrektorzy, prezesi, kierownicy w urzędach i instytucjach państwowych - muszą oni w krótkim czasie podejmować decyzje istotne dla całej organizacji. Ostatni sposób pisania dostosowany jest do osób z niepełnosprawnością intelektualną lub problemami neu- 
rologicznymi. Mogą one dekodować tylko uproszczone komunikaty, ponieważ ich choroba nie pozwala im na pełną przetworzenie informacji (Piekot 2018a).

Oto zasady upraszczania tekstów według modelu wrocławskiego:

1. Reguły dotyczące merytoryki:

- Dodaj istotne dla czytelnika treści merytoryczne.

- Usuń lub zdefiniuj terminy (słowa specjalistyczne).

2. Reguły dotyczące struktury tekstu:

- Informacje identyfikujące typ tekstu oraz sprawę umieszczaj w metryce dokumentu.

- Podstawy prawne umieszczaj pod tekstem.

- Tekst rozpoczynaj od streszczenia.

- Twórz nawigację ze śródtytułów.

3. Reguły dotyczące frazowania myśli:

- Kolejne myśli zamykaj w osobnych zdaniach.

- Unikaj zdań dłuższych niż 20 wyrazów.

- W każdym zdaniu pilnuj informacyjnego rdzenia, czyli struktury: podmiot-orzeczenie-dopełnienie.

- Unikaj zjawisk gramatycznych, które zmieniają naturalny porządek informacji w zdaniu (strona bierna; rzeczowniki odczasownikowe; bezosobowe formy czasownika; imiesłowy z cząstką -ąc).

4. Reguły dotyczące relacji nadawczo-odbiorczych:

- Często ujawniaj w tekście swoją obecność jako „ja” lub „my”.

- Często zwracaj się do czytelnika bezpośrednio.

- Nie wywyższaj się.

- Nie poniżaj odbiorcy (Piekot 2018a: 2-5).

Wymienione reguły prostej polszczyzny wykorzystano $\mathrm{w}$ procesie oceniania przystępności tekstów eksperymentalnych Banku Światowego oraz Krajowej Administracji Skarbowej.

\section{Założenia polskiego eksperymentu behawioralnego}

Eksperyment Banku Światowego oraz Krajowej Administracji Skarbowej wykorzystujący ekonomię behawioralną w zwiększeniu ściągalności podatków w Polsce wzorował się na badaniu przeprowadzonym w Wielkiej Brytanii. Kraj ten wspierał Polskę w 2015 roku, kiedy zaczęto wdrażać omawianą w niniejszym artykule strategię behawioralną $\mathrm{w}$ sferze administracji podatkowej, która polegała na porównywaniu wyników uzyskanych $\mathrm{z}$ wysłania pisma standardowego $\mathrm{z}$ wynikami pisma behawioralnego. Na potrzeby eksperymentu wysłano dziesięć pism (standardowe pismo $\mathrm{z}$ upomnieniem, bazowe pisma behawioralne oraz osiem pism behawioralnych z akapitami zawierającymi zróżnicowany komunikat perswazyjny) do 149925 
polskich obywateli zalegających z zapłatą podatku przekraczającą 50 złotych. Podatnicy byli losowo podzieleni na grupy i część z nich otrzymywała tradycyjne pismo, część natomiast jedno z dziewięciu pism behawioralnych. Pisma wysyłano listem zwykłym. Na podstawie tego badania autorzy eksperymentu wyciągnęli pięć następujących wniosków:

1. pisma behawioralne były skuteczniejsze niż standardowe pisma,

2. komunikat napisany w tonie surowym był skuteczniejszy od komunikatu napisanego w tonie łagodnym,

3. skuteczność pism behawioralnych była uzależniona od wieku i płci obywatela, a także od należnej kwoty oraz od miejsca, w którym przebywał podatnik,

4. wysyłka listem zarówno zwykłym, jak i poleconym była równie efektywna,

5. wykorzystanie pism $\mathrm{z}$ akapitami perswazyjnymi może być przyjęte $\mathrm{w}$ procedurze ściągalności podatków.

W niniejszym artykule przedstawiono analizę porównawczą pism behawioralnych wykorzystywanych w eksperymencie przeprowadzonym w 2016 roku. Pisma te skonfrontowano z zasadami prostego języka, by zbadać, które z nich są napisane prostym językiem i czy można wysnuć wspólne wnioski z obu eksperymentów.

\section{Analiza pragmalingwistyczna}

Pisma eksperymentalne są tworzone na potrzeby badań, a zatem należy rozstrzygnąć kwestie prawne pism behawioralnych i znaleźć odpowiedź na pytanie: czy pisma eksperymentalne są upomnieniami w świetle polskiego prawa? Na podstawie przepisów (rozporządzenie Ministra Finansów z dnia 30 grudnia 2015 roku w sprawie postępowania wierzycieli należności pieniężnych; ustawa z dnia 29 sierpnia 1997 roku Ordynacja podatkowa 1997) można stwierdzić, że każde pismo behawioralne $\mathrm{w}$ świetle polskiego prawa jest upomnieniem ${ }^{1}$.

Do zbioru pism eksperymentalnych (nie licząc standardowego upomnienia wysyłanego pocztą zwykłą) należą bazowe pismo behawioralne oraz osiem pism behawioralnych (dostępnych do wglądu w załącznikach do niniejszego artykułu): pismo odwołujące się do normy społecznej; pismo odwołujące się do dobra publicznego, zredagowane $\mathrm{w}$ tonie pozytywnym; pismo odwołujące się do dobra publicznego, zredagowane $\mathrm{w}$ tonie negatywnym; pismo $\mathrm{z}$ ostrzeżeniem; pismo $\mathrm{z}$ ostrzeżeniem i tytułem wykonawczym; pismo o przeoczeniu; pismo o przeoczeniu z elementami ostrzeżenia; przeoczenie-perspektywa podatnika.

Wymienione pisma w swojej strukturze różnią się od bazowego pisma behawioralnego jedynie fragmentem tekstu, który nawiązuje do tytułu i zmienia się w zależności od rodzaju komunikatu. Bazowe pismo behawioralne, jak też pismo beha-

1 Konsultacja prawna z dr. Łukaszem Prusem w Instytucie Nauk Administracyjnych Uniwersytetu Wrocławskiego; Wrocław 27.11.2018. 
wioralne z dodatkowym akapitem, są strukturalnie identyczne, różnią się jedynie występowaniem akapitu behawioralnego, który decyduje o charakterze wydźwięku komunikatu.

W piśmie odwołującym się do normy społecznej występuje fragment tekstu, który wspomina o regułach i normach funkcjonujących wśród wspólnoty. Można wnioskować, że ludzie chętniej wykonują czynności, które są praktykowane przez większość społeczeństwa (Hernandez et al. 2017: 15).

Pismo odwołujące się do dobra publicznego, zredagowane w tonie pozytywnym, polega na przedstawieniu przydatnych dla społeczeństwa korzyści wynikających z zapłaty podatków. Przedstawienie korzyści płynących z uregulowania kwoty sprawia, że adresat dostający list $\mathrm{z}$ upomnieniem czuje, że powinien zapłacić zaległą należność, gdyż wtedy przyczynia się on do polepszenia warunków życia prywatnego oraz publicznego.

Kolejnym pismem jest pismo odwołujące się do dobra publicznego, zredagowane $\mathrm{w}$ tonie negatywnym. Różnica między pismem zredagowanym $\mathrm{w}$ tonie pozytywnym a negatywnym polega na tym, że w tym drugim przypadku to nie zysk z płacenia podatków, lecz strata $\mathrm{z}$ powodu niepłacenia zaległych pieniędzy ma wpływać na zachowanie adresata i motywować go do uregulowania należnej kwoty. W analizowanym tekście nadawca komunikuje nie wprost, że adresat niepłacący podatków uniemożliwia rozwój gminy. Dodatkowo jest aluzją do tego, by adresat zapłacił podatek.

Pismo z ostrzeżeniem ma natomiast trzy cele: wywołać negatywne emocje wśród odbiorców, zażenowanie oraz poczucie winy; wzbudzać wrażenie, że groźba jest poważna; działać na wyobraźnię adresata, przywołując obrazy oraz imaginacje sytuacji związanych $\mathrm{z}$ nałożeniem kary w razie niewykonania polecenia (Hernandez et al. 2017: 16). Ostrzeżenie polega na zasygnalizowaniu niebezpieczeństwa, które wyniknie z podjęcia określonej czynności. W treści pisma znajdują się działania, które mogą zostać podjęte, jeśli obywatel nie zapłaci podatku. Jest to jedynie ostrzeżenie, ale użycie leksyki z obszaru prawa - na przykład postępowanie egzekucyjne - powoduje, że pismo nabiera oficjalnego tonu i trudniej je zbagatelizować. Dodatkowo odbiorca powinien dojść do wniosku, że uiszczenie kwoty podatku to lepsze rozwiązanie niż blokada środków pieniężnych na jego koncie czy wszczęcie procesu sądowego. W konsekwencji wywiązanie się z obowiązków podatnika wydaje się najrozsądniejszym rozwiązaniem, co powinno skłonić adresata do zapłaty zaległej kwoty.

Pismo z ostrzeżeniem i tytułem wykonawczym ma pogłębić ustalone wcześniej cele pisma. Dodatkowo załączenie wzoru dokumentu, który w praktyce wysyłany jest obywatelom zalegającym z uregulowaniem pieniędzy, powoduje, że ostrzeżenie oraz widmo kary i zobowiązań mogących ciążyć na podatniku w przypadku braku zapłaty staje się realniejsze. Adresat spoglądający na tytuł wykonawczy oraz czytający jego treść powinien czuć obawę i lęk przed konsekwencjami wynikającymi $\mathrm{z}$ niepłacenia podatków. 
Pismo o przeoczeniu to przykład komunikatu, w którym działania podatnika są monitorowane i poddawane ocenie. Jednocześnie podkreślone zostało to, iż podatnik nie wywiązuje się z obowiązku obywatelskiego i jest to jego świadoma decyzja. Wart podkreślenia jest fakt, że odbiorca będzie oceniany z punktu widzenia urzędu skarbowego, ponieważ instytucja wyda opinię, czy obywatel jest uczciwy czy też nie.

W kolejnym typie pisma połączono dwa elementy - przeoczenie oraz ostrzeżenie - aby sprawdzić, czy kontaminacja odczuć, takich jak poczucie moralności oraz strachu wynikającego $z$ ostrzegania i przedstawiania konsekwencji niepłacenia podatków jest skuteczniejsza od każdego z tych elementów zawartego w osobnym komunikacie (Hernandez et al. 2017: 17).

Przeoczenie-perspektywa podatnika stanowi tekst wymuszający w odbiorcy autorefleksję na temat własnych działań i decyzji. Autorzy tego pisma uważali, że dla człowieka istotna jest samoocena, która może tworzyć motywację do działań, $\mathrm{w}$ tym przypadku do zapłaty podatku. W przeciwieństwie do wymienionych pism komunikat ten sugeruje odbiorcy, że powinien on siebie wartościować jako złego podatnika, jeśli nie podejmie określonych w piśmie działań. W roli oceniającego podatnika występuję tu sam odbiorca, nie urząd.

Osobnym wątkiem pragmalingwistycznym, tu jedynie zasygnalizowanym, jest problem perswazji i manipulacji pism behawioralnych. Autorzy eksperymentu twierdzą, że wszystkie behawioralne pisma eksperymentalne jawnie nakłaniają podatnika do zapłaty - odbiorca ma świadomość, że wysłany do niego list z upomnieniem ma spowodować uregulowanie długu wobec państwa. Analiza pragmalingwistyczna wykazała jednak, że w upomnieniach zredagowanych na potrzeby eksperymentu są zawarte komunikaty, które za pomocą presupozycji i implikatur wpływają niejawnie na działania odbiorcy, a zatem reprezentują takie zjawisko jak manipulacja (Austin 1962; Kamińska-Szmaj 2004).

Szczegółowe porównanie pism wysłanych $\mathrm{w}$ ramach eksperymentu pozwala wykryć kilka nieścisłości, dotyczących głównie różnic w językowym kształcie pism wysłanych pocztą zwykłą i listem poleconym. Oto lista owych różnic:

- warstwa leksykalna: w piśmie wysyłanym pocztą poleconą występowało gerundium upomnienie jako słowo nazywające wysyłany dokument, natomiast w piśmie wysyłanym pocztą zwykłą użyto wyrazu pismo;

- relacyjność: zmiana wzywaja na czasownik bezosobowy wzywa się występujący w piśmie wysyłanym pocztą zwykłą w wyrażeniu wzywaja do uregulowania i wzywa się do uregulowania. Ten dobór słownictwa wpływa na parametr, który dotyczy relacyjności w tekście. Czasownik określa nadawcę - gdy się on nie pojawia, nie występują też językowe wyznaczniki nadawcy, jak jest w przypadku pisma wysyłanego pocztą zwykłą. Dodatkowo w piśmie wysyłanym pocztą zwykłą zmieniono tryb czasownika z oznajmującego spowoduje na przypuszczający może spowodować, co związane jest również z osobową i nieosobową formą czasownika; 
- struktura: $\mathrm{w}$ standardowym piśmie z upomnieniem wysyłanym pocztą zwykłą usunięto tytuł pisma, numer oraz datę, a także jeden wiersz w tabeli pod tytułem Koszty upomnienia;

- daty: w piśmie wysyłanym pocztą zwykłą podano datę 2005 rok, natomiast, według przypisów autorów, powinien być podany rok 2015 (Hernandez et al. 2017: 14).

\section{Analiza stylometryczna}

Analiza stylometryczna polega na zbadaniu dziesięciu pism pod kątem piętnastu parametrów podzielonych na trzy grupy:

- głównych indeksów mglistości tekstów,

- parametrów leksykalnych,

- parametrów gramatycznych.

Cechy te dzielą się na parametry liczone automatycznie, to znaczy komputerowo - należą do nich: średnia długość zdania, stosunek rzeczowników do czasowników, odsetek trudnych słów, odsetek długich słów, indeks FOG (Gunning 1952), indeks T Walerego Pisarka (1969), stopień trudności tekstu według Jasnopisu oraz liczone ręcznie: odsetek rzeczowników abstrakcyjnych, odsetek słownictwa perswazyjnego, odsetek wykładników językowych odbiorcy, odsetek wykładników językowych nadawcy, odsetek strony biernej, odsetek form czasowników bezosobowych, indeks ukrytych czynności, współczynnik bogatego słownictwa. Numeracja pism na wykresach i w tabelach jest ustalona według miejsca $\mathrm{w}$ rankingu $\mathrm{z}$ eksperymentu (zob. aneks): miejsce 1 - pismo o przeoczeniu z elementami ostrzeżenia, czyli pismo w eksperymencie najskuteczniejsze; 2 - pismo o przeoczeniu; 3 - pismo z ostrzeżeniem i tytułem wykonawczym; 4 - przeoczenie-perspektywa podatnika; 5 - bazowe pismo behawioralne; 6 - pismo odwołujące się do dobra publicznego, zredagowane $\mathrm{w}$ tonie pozytywnym; 7 - pismo $\mathrm{z}$ ostrzeżeniem; 8 pismo odwołujące się do normy społecznej; 9 - pismo odwołujące się do dobra publicznego, zredagowane $\mathrm{w}$ tonie negatywnym; $10-$ standardowe upomnienie, najmniej skuteczne pod względem ściągalności podatków.

Ogólna mglistość. Główne miary mglistości tekstu to indeks FOG, wzór Walerego Pisarka oraz indeks Jasnopisu. Wyniki sortowania pism z perspektywy tych miar przedstawia wykres 1.

Analizując wykres, należy stwierdzić, iż wzór T Pisarka, indeks FOG Gunninga, a także indeks Jasnopisu tworzą dość podobne rankingi pism, które jednak znacznie odbiegają od rankingu z eksperymentu. Najskuteczniejsze pismo w eksperymencie (1) według zastosowanych wzorów jest dość trudne (według wzoru Pisarka jest dopiero na siódmym miejscu pod względem prostoty, według indeksu FOG — na szóstym). 
Trudność pism z eksperymentu w świetle miar mglistości języka

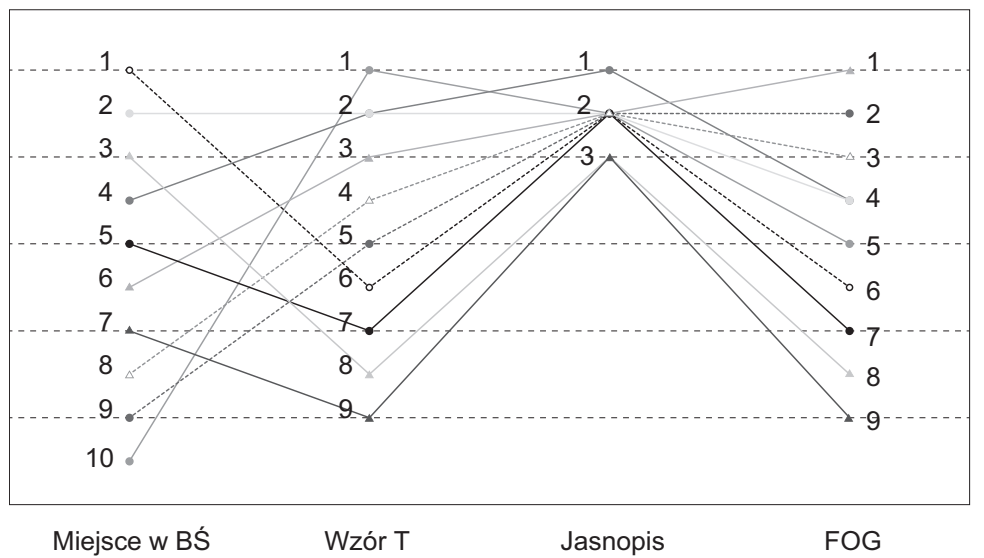

Wykres 1. Analiza Stylometryczna (na osi pionowej od lewej: numer pisma w rankingu BŚ i KAS; ranking na podstawie wzoru T; ranking Jasnopisu; ranking na podstawie indeksu FOG)

Źródło: opracowanie własne.

Leksyka. Rzeczowniki abstrakcyjne, odsetek trudnych słów, współczynnik bogatego słownictwa, odsetek językowych wyznaczników nadawcy, odsetek językowych wyznaczników odbiorcy oraz odsetek trudnych słów - są to parametry leksykalne. Wszystkie wyniki uzyskane na podstawie analizy ilościowej dotyczącej parametrów leksykalnych znajdują się w poniższej tabeli (tabela 1).

Tabela 1. Rankingi pism pod względem cech leksykalnych. Pozycja w rankingu to jednocześnie liczba punktów

\begin{tabular}{|l|c|c|c|c|c|c|c|c|c|c|}
\hline \multicolumn{1}{|c|}{ Typ rankingu } & \multicolumn{7}{|c|}{ Miejsce pisma na liście rankingowej } \\
& \multicolumn{1}{|c|}{ (= liczba punktów) } \\
\hline miejsce pisma według rankingu BŚ & 6 & 9 & 1 & 2 & 4 & 3 & 8 & 7 & 5 & 10 \\
\hline odsetek rzeczowników abstrakcyjnych & 10 & 10 & 9 & 6 & 6 & 7 & 8 & 5 & 6 & 4 \\
\hline odsetek wykładników odbiorcy & 10 & 10 & 9 & 9 & 9 & 7 & 8 & 8 & 8 & 6 \\
\hline odsetek wykładników nadawcy & 8 & 8 & 10 & 10 & 9 & 10 & 9 & 9 & 9 & 7 \\
\hline odsetek trudnych słów & 10 & 10 & 8 & 9 & 9 & 7 & 9 & 8 & 9 & 8 \\
\hline współczynnik bogatego słownictwa & 8 & 9 & 7 & 8 & 7 & 6 & 5 & 4 & 6 & 10 \\
\hline odsetek słownictwa perswazyjnego & 7 & 6 & 8 & 7 & 7 & 9 & 6 & 10 & 5 & 4 \\
\hline suma & $\mathbf{5 3}$ & $\mathbf{5 3}$ & $\mathbf{5 1}$ & $\mathbf{4 9}$ & $\mathbf{4 7}$ & $\mathbf{4 6}$ & $\mathbf{4 5}$ & $\mathbf{4 4}$ & $\mathbf{4 3}$ & $\mathbf{3 9}$ \\
\hline $\begin{array}{l}\text { ranking według parametrów } \\
\text { leksykalnych }\end{array}$ & 1 & 1 & 2 & 3 & 4 & 5 & 6 & 7 & 8 & 9 \\
\hline
\end{tabular}

Źródło: opracowanie własne. 
Zestawienie to pokazuje, że najskuteczniejsze pismo z eksperymentu (1), pod względem cech leksykalnych, zajmuje drugie miejsce. Oznacza to, że jest prostsze od większości wysłanych pism. Liderami tego rankingu są pisma (6) oraz (9), które odwołują się do dobra publicznego. Standardowe upomnienie (10) zajmuje ostatnie miejsce.

Gramatyka. Do trzeciej grupy zalicza się takie parametry, jak: odsetek strony biernej, odsetek czasowników bezosobowych, odsetek rzeczowników odczasownikowych (ukrytych czynności), stosunek rzeczowników do czasowników, odsetek długich słów oraz średnia długość zdania. Parametry gramatyczne istotnie wpływają na poziom trudności tekstów. Wyniki dotyczące niniejszych parametrów przedstawiono w tabeli (tabela 2).

Tabela 2. Rankingi pism pod względem parametrów gramatycznych. Pozycja w rankingu to jednocześnie liczba punktów

\begin{tabular}{|l|c|c|c|c|c|c|c|c|c|c|}
\hline \multicolumn{1}{|c|}{ Typ rankingu } & \multicolumn{7}{|c|}{ Miejsce pisma na liście rankingowej } \\
(= liczba punktów) \\
\hline miejsce pisma według rankingu BŚ & 4 & 8 & 6 & 1 & 3 & 2 & 9 & 7 & 5 & 10 \\
\hline odsetek strony biernej & 10 & 9 & 6 & 3 & 8 & 5 & 6 & 7 & 7 & 4 \\
\hline $\begin{array}{l}\text { odsetek form czasowników } \\
\text { bezosobowych }\end{array}$ & 9 & 8 & 10 & 7 & 6 & 5 & 5 & 6 & 4 & 3 \\
\hline indeks ukrytych czynności & 6 & 9 & 10 & 7 & 5 & 4 & 10 & 5 & 8 & 3 \\
\hline $\begin{array}{l}\text { stosunek rzeczowników do } \\
\text { czasowników }\end{array}$ & 7 & 5 & 4 & 9 & 8 & 10 & 4 & 6 & 3 & 2 \\
\hline odsetek długich słów & 9 & 6 & 7 & 10 & 8 & 9 & 7 & 7 & 6 & 6 \\
\hline średnia długość zdania & 9 & 10 & 9 & 9 & 10 & 9 & 9 & 9 & 8 & 10 \\
\hline suma & $\mathbf{5 0}$ & $\mathbf{4 7}$ & $\mathbf{4 6}$ & $\mathbf{4 5}$ & $\mathbf{4 5}$ & $\mathbf{4 2}$ & $\mathbf{4 1}$ & $\mathbf{4 0}$ & $\mathbf{3 6}$ & $\mathbf{2 8}$ \\
\hline miejsce według parametrów & 1 & 2 & 3 & 4 & 4 & 5 & 6 & 7 & 8 & 9 \\
\hline
\end{tabular}

Źródło: opracowanie własne.

Podsumowując wyniki dotyczące parametrów gramatycznych, można zauważyć, że najlepsze pismo według rankingu Banku Światowego (1) zajęło czwarte miejsce (pismo o przeoczeniu z elementami ostrzeżenia). Klasyczne pismo (10) zajęło ostatnie miejsce. Pismem zdobywającym największą liczbę punktów okazało się przeoczenie-perspektywa podatnika (4).

Ranking końcowy. Pora wreszcie na ranking końcowy. Zsumowane w nim zostały punkty wynikające z pozycji w trzech głównych rankingach: pod względem głównych miar, pod względem parametrów leksykalnych oraz pod względem parametrów gramatycznych. W tabeli 3 zawarto informacje na temat końcowej sumy punktów uzyskanych przez poszczególne pisma oraz ich pozycji w końcowym rankingu. 
Tabela 3. Ranking końcowy. Suma punktów zdobytych przez pisma w trzech rankingach lingwistycznych (mglistość tekstu, parametry leksykalne oraz parametry gramatyczne)

\begin{tabular}{|l|c|c|c|c|c|c|c|c|c|c|}
\hline \multicolumn{1}{|c|}{ Typ rankingu } & \multicolumn{7}{|c|}{ Miejsce pisma na liście rankingowej } \\
[= liczba punktów)
\end{tabular}

Źródło: opracowanie własne.

Z tabeli 3 wynika, że pismo, które w eksperymencie behawioralnym zdobyło pierwsze miejsce, po analizie stylometrycznej znajduje się na miejscu piątym. Na pierwszym miejscu znajduje się pismo odwołujące się do dobra publicznego, zredagowane w tonie pozytywnym - ono jest najprostsze. Drugie miejsce zajęło przeoczenie z perspektywy podatnika. Trzecie miejsce należy do pisma odwołującego się do dobra publicznego, zredagowane w tonie negatywnym. Pismo (1) okazało się dużo prostsze od innych pism tylko pod względem leksykalnym (tam zajęło drugie miejsce).

\section{Propozycja nowego pisma}

Wypada teraz zapytać, czy możliwe jest połączenie ekonomii behawioralnej z zasadami prostego języka. Odpowiedzią jest wzór pisma (11), będącego uzupełnieniem pisma (1) o zasady prostego języka. Oczywiście, wypracowany tekst także został poddany analizie pod względem głównych miar, parametrów leksykalnych oraz gramatycznych. Dzięki temu można porównać cechy językowe oryginału i pisma proponowanego (tabela 4). Litera $\mathrm{N}$ to pismo proponowane, numer 1 to najskuteczniejsze pismo behawioralne, a numer 6 to najprostsze pismo behawioralne.

Nowe pismo (11) według trzech grup parametrów jest najlepszym pismem zajmuje pierwsze miejsce $\mathrm{z}$ różnicą aż dwudziestu trzech punktów. Biorąc pod uwagę wcześniejsze wyniki z podsumowana ogólnego dziesięciu pism, jest to znacząca przewaga punktowa, co oznacza, że w znacznej części badanych parametrów to pismo (11) uzyskało maksymalną liczbę punktów (na przykład główny wynik Jasnopisu, wzór Pisarka). Na piętnaście badanych parametrów, pismo z elementami przeoczenia i ostrzeżenia napisane stylem prostej polszczyzny uzyskało maksymalne wyniki (10 punktów) w dziesięciu z nich. 
Tabela 4. Podsumowanie wyników upomnienie z ekonomią behawioralną i prostym językiem

\begin{tabular}{|l|c|c|c|c|c|c|c|c|c|c|c|}
\hline \multicolumn{1}{|c|}{ Typ rankingu } & \multicolumn{8}{c|}{ Miejsce pisma na liście rankingowej } \\
[= liczba punktów) \\
\hline $\begin{array}{l}\text { miejsce pisma według rankingu } \\
\text { BS }\end{array}$ & $\mathrm{N}$ & 6 & 4 & 9 & 2 & 1 & 8 & 3 & 7 & 5 & 10 \\
\hline suma pkt głównych miar & 28 & 25 & 23 & 22 & 22 & 16 & 21 & 11 & 9 & 14 & 22 \\
\hline $\begin{array}{l}\text { suma pkt parametrów } \\
\text { leksykalnych }\end{array}$ & 53 & 51 & 44 & 51 & 46 & 49 & 42 & 35 & 40 & 38 & 31 \\
\hline $\begin{array}{l}\text { suma pkt parametrów } \\
\text { gramatycznych }\end{array}$ & 58 & 40 & 45 & 35 & 37 & 40 & 41 & 39 & 34 & 30 & 22 \\
\hline $\begin{array}{l}\text { suma pkt wszystkich } \\
\text { parametrów z trzech grup }\end{array}$ & $\mathbf{1 3 9}$ & $\mathbf{1 1 6}$ & $\mathbf{1 1 2}$ & $\mathbf{1 0 8}$ & $\mathbf{1 0 5}$ & $\mathbf{1 0 5}$ & $\mathbf{1 0 4}$ & $\mathbf{8 5}$ & $\mathbf{8 3}$ & $\mathbf{8 2}$ & $\mathbf{7 5}$ \\
\hline $\begin{array}{l}\text { miejsce pisma według trzech } \\
\text { grup parametrów }\end{array}$ & 1 & 2 & 3 & 4 & 5 & 5 & 6 & 7 & 8 & 9 & 10 \\
\hline
\end{tabular}

Źródło: opracowanie własne.

\section{Konkluzje}

Na podstawie analizy ilościowej pism behawioralnych, standardowego upomnienia oraz pisma proponowanego można wysnuć następujące wnioski:

1. Wszystkie pisma zredagowane na potrzeby eksperymentu Banku Światowego są przystępniejsze od standardowego pisma.

2. Pismo, które w rankingu Banku Światowego i Krajowej Administracji Skarbowej zdobyło pierwsze miejsce (przyniosło najwięcej pieniędzy), jest prostsze od niektórych pism użytych w eksperymencie (piąte miejsce w kolejności). Oznacza to, że wysłane do podatników pisma nie były napisane w jednakowy sposób. Najskuteczniejsze pismo było szczególnie proste w zakresie leksyki.

3. Najprostsze pismo behawioralne to pismo odwołujące się do dobra publicznego, zredagowane w tonie pozytywnym. Drugie miejsce zajęło przeoczenie-perspektywa podatnika. Trzecie miejsce należy do pisma odwołującego się do dobra publicznego, zredagowanego w tonie negatywnym. Pod względem uzyskanych przychodów pisma te w rankingu Banku Światowego uzyskały następujące wyniki: pismo odwołujące się do dobra publicznego, zredagowane w tonie pozytywnym - dziewiąte miejsce; przeoczenie-perspektywa podatnika - czwarte miejsce; pismo odwołujące się do dobra publicznego, zredagowane w tonie negatywnym - ósme miejsce.

4. Badając przystępność pism, należy analizować wiele aspektów tekstu (strukturę, leksykę oraz gramatykę), aby móc stwierdzić, w jakim stopniu dany tekst jest trudny. Tylko szczegółowe porównanie różnorodnych parametrów sprawia, że ocena prostoty języka będzie wiarygodna. Uznanie tylko głównych wskaźników mglistości za najważniejsze nie umożliwia uzyskania wiarygodnych danych, ponieważ 
formuły analityczne badają wiele zmiennych czynników jednocześnie, czasami je uśredniając, co w konsekwencji nie daje jednoznacznego wyniku. Badania te są komplementarne i należy je stosować przy analizie tekstów, wykorzystując dodatkowo inne metody badań oceny trudności tekstu. Wyróżniającą cechą pism behawioralnych jest budowanie relacji między nadawcą a odbiorcą (przeplatanie się wykładników nadawcy i odbiorcy).

5. Obiecujące może być połączenie w jednym piśmie obu strategii komunikacji, to znaczy zasad prostego języka oraz ekonomii behawioralnej. Pismo to może być skuteczniejsze przez lepszy dostęp do informacji.

6. Najłatwiej upraszczać pisma pod względem gramatyki i składni, najtrudniej zaś zmieniać leksykę tekstu, szczególnie, gdy temat komunikatu determinuje wybór słownictwa.

Na zakończenie warto podkreślić, że opisany tu eksperyment behawioralny był pierwszym, gdy polski urząd podjął się wprowadzenia zmian językowych, aby zwiększyć ściągalność zaległego podatku. Zmiana stylu komunikacji, czyli wykorzystanie strategii językowych ekonomii behawioralnej, sprawiła, że pisma wysyłane do podatników stały się skuteczniejsze. Ich efektywność potwierdziły zadowalające rezultaty w postaci wzrostu uregulowania zaległych kwot podatkowych. Na uwagę zasługuje wniosek, iż kwoty wniesionych płatności były znacząco większe niż sam koszt eksperymentu. Całkowity koszt badania wyniósł 1413133 złotych, natomiast korzyści wynikające z eksperymentu to 88741023 złotych (netto), co oznacza, że badanie to było opłacalne i zakończyło się sukcesem (Hernandez et al. 2017: 31).

Warto zatem badać efektywność tekstów urzędowych w praktyce, ponieważ badania takie przynoszą korzyści urzędom, obywatelom i samym naukowcom.

\section{Bibliografia}

Austin J. (1962): How to Do Things with Words, Oxford.

Gunning R. (1952): Technique of Clear Writing, New York.

Hallsworth M., List A.J., Metcalfe D.R., Vlaev I. (2014): The Behavioralist As Tax Collector: Using Natural Field Experiments to Enhance Tax Compliance, Chcago.

Hernandez M., Jamison J., Korczyc E., Mazar N., Sormani R. (2017): Zastosowanie technik behawioralnych $w$ celu poprawy ściagalności podatków. Wyniki badań empirycznych przeprowadzonych $w$ Polsce, Word Bank Group, http://www.mf.gov.pl/c/document_library/get_file?uuid=0b69a813-fdec4f09-86b3-171618a2a5a4\&groupId=764034 (dostęp 16.12.2017).

Jasnopis (2019): www.jasnopis.pl/\#aplikacja (dostęp: 10.04.2019).

Kamińska-Szmaj I. (2004): Propaganda, perswazja, manipulacja: próba uporządkowania pojęć, [w:] Manipulacja w jezzyku, red. P. Krzyżanowski, P. Nowak, Lublin.

Lem (2019): https://ws.clarin-pl.eu/lem.shtml (dostęp: 26.03.2019).

Logios Research (2019): http://www.logios.pl/ (dostęp: 19.03.2019).

Olejniczak K., Śliwowski P. (2014): Nadchodzi rewolucja? Analizy behawioralne w interwencjach publicznych, [w:] (R)ewaluacja 2. Wiedza w działaniu, red. A. Haber, K. Olejniczak, Warszawa. 
Piekot T. (2018a): Efektywna komunikacja pisemna. Skrypt dla stuchaczy studiów podyplomowych pt. „Akademia Oceny Skutków Regulacji”, Wrocław.

Piekot T. (2018b): Prosta polszczyzna. Standard Uniwersytetu Wrocławskiego, materiały z seminarium magisterskiego.

Pisarek W. (1969): Jak mierzyć zrozumiałość tekstu? „Zeszyty Prasoznawcze” nr 4(42).

Rozporządzenie Ministra Finansów z dnia 30 grudnia 2015 r. w sprawie postępowania wierzycieli należności pieniężnych (2015): Dz.U. 2015 poz. 2367.

Solek A. (2010): Ekonomia behawioralna a ekonomia neoklasyczna, „Zeszyty Naukowe” nr 8.

Ustawa z dnia 29 sierpnia 1997 r. Ordynacja podatkowa (1997) Dz.U. Nr 137, poz. 926.

\section{An experiment by the World Bank and the National Revenue Administration in the light of plain language principles}

Summary

In the article the author presents the principles of plain language and behavioural economy in official communication. She discusses a study whose aim was to verify whether the effectiveness of behavioural economy used in official letters created for the purpose of an experiment conducted by the World Bank and the National Revenue Administration in Poland in 2016 (Hernandez et al. 2017) was linked to the principles of plain language. In addition, she compares the results of the World Bank's experiment with the results of a (qualitative and quantitative) linguistic analysis carried out in the presented article. The author seeks to verify whether letters regarded by the World Bank as the most effective in terms of tax collection will also be those best conforming to the rules of plain language. The hypothesis formulated in the article assumes that the letters written for the purpose of the experiment have varying levels of difficulty, which means - contrary to the experimenters' assumptions - that they differ in terms of not only their persuasion technique (the so-called behavioural insight), but also style. If the hypothesis were to be confirmed, this would obviously undermine the conclusions of the experiment.

Keywords: National Revenue Administration, behavioural economy, official communication, manipulation, citizen, persuasion, letter, plain language, tax, plain Polish, text accessibility, reminder. 


\section{ANEKS}

1. Tradycyjne pismo z upomnieniem, wysłane pocztą poleconą

NACZELNIK URZĘDU SKARBOWEGO W ŻARACH

ŻARY, OSADNIKÓW WOJSKOWYCH 3

Numer tel.: 6844560500

NIP.

\section{Za potwierdzeniem odbioru}

\section{UPOMNIENIE}

Nr. 466/15

$\mathrm{Z}$ dnia 23.05.2016

Na podstawie art. $15 \$ 1$ ustawy z dnia 17 czerwca 1966r. o postępowaniu egzekucyjnym w administracji (Dz.U. z 2014r. poz. 1619 - tekst jednolity) wzywają do uregulowania:

\begin{tabular}{|c|c|c|c|c|c|}
\hline Lp. & Rodzaj należności & Okres & $\begin{array}{c}\text { Kwota } \\
\text { należności } \\
\text { w zł }\end{array}$ & $\begin{array}{c}\text { *Odsetki } \\
\text { na dzień } \\
\text { wystawienia } \\
\text { upomnienia w zł }\end{array}$ & Suma \\
\hline 1. & PODATEK PIT (ZOB-D) & $1 / 2014$ & 30,00 & 3,00 & 33,00 \\
\hline 2. & PODATEK PIT (ZOB-D) & $2 / 2014$ & 123,00 & 11,00 & 134,00 \\
\hline 3. & Koszty upomnienia & $\mathrm{X}$ & $\mathrm{X}$ & $\mathrm{X}$ & 11,60 \\
\hline 4. & Razem & $\mathrm{X}$ & $\mathrm{X}$ & $\mathrm{X}$ & 178,60 \\
\hline
\end{tabular}

Typ odsetek - odsetki podatkowe

Stawka dalszych odsetek - 8\%

Wzywa się do wykonania obowiązku objętego niniejszym upomnieniem w terminie 7 dni od dnia doręczenia upomnienia. Kwotę należności wraz z odsetkami naliczonymi na dzień wpłaty i kosztami upomnienia należy wpłacić do kasy za pośrednictwem Poczty Polskiej lub na rachunek bankowy NBP/O/OKR in Zielona Góra no. 12101017040055262223000000 .

Niewykonanie obowiązku we wskazanym terminie spowoduje skierowanie sprawy na drogę postępowania egzekucyjnego, wskutek czego powstanie obowiązek uiszczenia kosztów egzekucyjnych, które zaspokajane są w pierwszej kolejność.

*Odsetki zostały naliczone na dzień wystawienia upomnienia. Dokonując wpłaty, należy doliczyć odsetki od kwoty należności od dnia następnego po wystawieniu upomnienia do dnia wpłaty. 
Przy wpłacie w pełnej wysokości kwoty należności wraz z odsetkami i kosztami upomnienia odsetki należy zaokrąglić do pełnych złotych . Nie pobiera się odsetek, jeżeli ich wysokość na dzień wpłaty nie przekracza kwoty 8,70 zł.

(podpis i pieczątka z podaniem imienia, nazwiska i stanowiska służbowego) 
2. Bazowe pismo behawioralne

W zaznaczonym miejscu eksperymentatorzy dodawali różne akapity behawioralne.

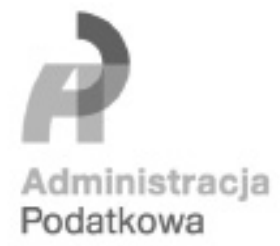

XXXXXXXX, dnia 23 maja 2016 r.

Jan Kowalski

Naczelnik Urzędu Skarbowego

URZĄD SKARBOWY XXXXXXXXXX

ul. XXXXXXXXXX

\section{Proszę zapłacić zaległy podatek dochodowy do 3 czerwca 2016 r.}

Szanowny Panie,

Z posiadanych przez nas informacji wynika, że nie zapłacił Pan podatku dochodowego za $2015 \mathrm{r}$.

[lokalizacja akapitu behawioralnego]

Jeżeli do 3 czerwca 2016 roku nie zapłaci Pan swojego zobowiązania w wysokości XXXX złotych wraz z odsetkami, zostanie wobec Pana wszczęte postępowanie egzekucyjne.

Proszę zapłacić całkowitą kwotę zobowiązania, jaką pokazano w tabeli na odwrocie tego pisma, przelewem bankowym na rachunek XX XXXX XXXX XXXX XXXX XXXX XXXX, za pośrednictwem operatora pocztowego, banku lub bezpośrednio w urzędzie skarbowym.

W przypadku braku możliwości uregulowania przez Pana pełnej kwoty od razu, albo w przypadku dodatkowych pytań, prosimy o pilny kontakt pod numerem telefonu XX XXX XX XX.

Będziemy monitorować Pana reakcję na to pismo.

Z wyrazami szacunku,

(Podpis i pieczątka Naczelnika US) 


\section{AKAPIT ODWOŁUJACY SIE DO NORMY SPOŁECZNEJ}

Jak wynika z naszych danych, 8 na 10 mieszkańców województwa mazowieckiego zapłaciło już podatek dochodowy za 2015 rok. Należy Pan do nielicznej grupy mieszkańców, którzy jeszcze nie spełnili tego obowiązku.

\section{AKAPIT ODWOŁUJĄCY SIĘ DO DOBRA PUBLICZNEGO, ZREDAGOWANY W TONIE POZYTYWNYM}

Czy ma Pan świadomość, że 37,79 procent Pana podatku dochodowego jest przekazywane do Pana gminy? Z tych dochodów, Pana gmina finansuje przedszkola, szkoły, drogi i bezpieczeństwo, które służą wszystkim mieszkańcom gminy, włącznie z Panem i Pana rodziną. Niech Pan nie będzie nieodpowiedzialnym mieszkańcem swojej gminy i zapłaci swój zaległy podatek!

\section{AKAPIT ODWOŁUJACY SIE DO DOBRA PUBLICZNEGO, ZREDAGOWANY W TONIE NEGATYWNYM}

Czy ma Pan świadomość, że 37, 79 procent Pana podatku dochodowego jest przekazywane do Pana gminy. Bez tych dochodów, Pana gmina nie może finansować przedszkoli, szkół, dróg i bezpieczeństwa, szkodząc wszystkim mieszkańcom gminy, włącznie z Panem i Pana rodziną. Niech Pan nie będzie nieodpowiedzialnym mieszkańcem swojej gminy i zapłaci swój zaległy podatek!

\section{AKAPIT Z OSTRZEŻENIEM}

Niepłacenie podatków nakłada niesprawiedliwe obciążenia na pozostałych podatników, którzy uczciwie wywiązali się z tego obowiązku. Jesteśmy zdeterminowani, bardziej niż kiedykolwiek, aby egzekwować należne podatki od tych, którzy unikają ich płacenia. W ramach egzekucji możemy między innymi zająć Pana rachunek bankowy, wynagrodzenie, a także będzie Pan dodatkowo zobowiązany do pokrycia kosztów postępowania egzekucyjnego.

\section{AKAPIT Z OSTRZEŻENIEM ORAZ Z INFORMACJĄ O TYTULE WYKONAW- CZYM}

Niepłacenie podatków nakłada niesprawiedliwe obciążenia na pozostałych podatników, którzy uczciwie wywiązali się z tego obowiązku. Jesteśmy zdeterminowani, bardziej niż kiedykolwiek, aby egzekwować należne podatki od tych, którzy unikają ich płacenia. W ramach egzekucji możemy między innymi zająć Pana rachunek bankowy, wynagrodzenie, a także będzie Pan dodatkowo zobowiązany do pokrycia kosztów postępowania egzekucyjnego.

\section{AKAPIT Z INFORMACJA O PRZEOCZENIU}

Do tej pory Pana opóźnienie w zapłacie należnego podatku mogliśmy uznać za przeoczenie. Jednak jeżeli zignoruje Pan to pismo, zmuszeni będziemy uznać, że jest to Pana świadomy wybór i zaczniemy Pana postrzegać jak nieuczciwego podatnika. 


\section{AKAPIT Z INFORMACJĄ O PRZEOCZENIU I Z ELEMENTEM OSTRZEŻE- NIENIA}

Do tej pory Pana opóźnienie w zapłacie należnego podatku mogliśmy uznać za przeoczenie. Jednak jeżeli zignoruje Pan to pismo, zmuszeni będziemy uznać, że jest to Pana świadomy wybór i zaczniemy Pana postrzegać jak nieuczciwego podatnika. W ramach egzekucji możemy między innymi zająć Pana rachunek bankowy, wynagrodzenie, a także będzie Pan dodatkowo zobowiązany do pokrycia kosztów postępowania egzekucyjnego.

AKAPIT O PRZEOCZENIU - NAPISANY Z PERSPEKTYWY PODATNIKA

Do tej pory Pana opóźnienie $\mathrm{w}$ zapłacie należnego podatku mogliśmy uznać za przeoczenie. Jednak jeżeli zignoruje Pan to pismo, powinien Pan uznać, że to Pana świadomy wybór i myśleć o sobie jako o nieuczciwym podatniku. 
3. Propozycja nowego pisma (ekonomia behawioralna + zasady prostego języka)

Urząd Skarbowy XXXX

ul. XXXX

Szanowny Pan

Jan Nowak

ul. XXXX

62-544 Warszawa

Upomnienie w sprawie zapłaty zaległego podatku

Numer sprawy $\quad \mathrm{XXX} / \mathrm{XX}$

Data

23.05.2016 r.

Szanowny Panie,

z naszych informacji wynika, że nie zapłacił Pan podatku dochodowego za rok 2015. Prosimy, aby zapłacił Pan zaległość do 3 czerwca 2016 roku. Jeżeli zignoruje Pan to pismo, uznamy, że jest to Pana świadomy wybór i zaczniemy Pana postrzegać jak nieuczciwego podatnika.

Poniżej przekazujemy Panu bardzo ważne informacje na ten temat.

\section{Zaległa kwota podatku}

23 maja kwota Pana podatku wynosi XXXX zł. Prosimy, aby sprawdził Pan ostateczną wysokość zaległości zgodnie z tabelą, którą umieściliśmy na odwrocie tego pisma.

\section{Sposób zapłaty zaległości}

Podatek może Pan zapłacić na trzy sposoby:

- osobiście - w Urzędzie Skarbowym przy ul. XXXX,

- na poczcie - w dowolnej placówce Poczty Polskiej,

- przelewem bankowym - na rachunek NBP/O/OKR in Zielona Góra no.

12101017040055262223000000 .

\section{Konsekwencje braku zapłaty}

Do tej pory Pana opóźnienie w zapłacie zaległości mogliśmy uznać za przeoczenie. Jednak, jeśli nie zapłaci Pan podatku w terminie, doliczymy odsetki, a także możemy zająć Pana rachunek bankowy i wynagrodzenie. Dodatkowo zapłaci Pan również za postępowanie egzekucyjne. 


\section{Kontakt}

Gdyby miał Pan jakiekolwiek pytania w tej sprawie, prosimy o kontakt pod numerem: XXXX.

$$
\begin{gathered}
\text { Z wyrazami szacunku } \\
\text { (podpis i pieczątka Naczelnika US) }
\end{gathered}
$$

\section{Podstawa prawna}

$\$ 4$ ust. 1 rozporządzenia $z$ dnia 30 grudnia 2015 r. Ministra Finansów w sprawie postępowania wierzycieli należności pieniężnych (Dz. U. z 2015 r., poz. 2367) 